\title{
MAPESA'S Role in Protecting Aceh Historical Site: (Study at Historical sites in Banda Aceh and Aceh Besar)
}

\author{
Anismar $^{1, *}$, Mohd Yusri Bin Ibrahim², Zikri Bin Muhammad ${ }^{2}$ and Jumadil Saputra ${ }^{2}$ \\ ${ }^{1}$ Lecturer of Communication Sciences, Faculty of Social and Political Science, Malikussaleh University, North \\ Aceh, Aceh, Indonesia, and Student of doctoral in Malaysia Terengganu University (UMT), Indonesia \\ ${ }^{2}$ Lecturer of Malaysia Terengganu University (UMT), Indonesia
}

\begin{abstract}
The title of this research is "The Role of MAPESA in Protecting Aceh Historical Sites (Study on historical sites in Banda Aceh and Aceh Besar)". This research focuses on the strategies used by the MAPESA Community (Masyarakat Peduli Sejarah Aceh) in introducing Aceh's history to the community, as well as the obstacles faced by the MAPESA community in preserving Aceh's historical heritage. The purpose of this research is to find out what strategies the MAPESA Community uses in introducing Aceh's history to the community as well as the obstacles that mapesa communities face as long as they preserve historical relics in Aceh, especially in Banda Aceh and Aceh Besar. This research uses a qualitative approach using the Laswell Model strategy theory. In order to obtain accurate data and informant, data collection techniques used are observation, interview, documentation, and literature studies to find additional references to the problems studied. The results showed that the strategy used by the MAPESA community in introducing Aceh history is two ways, namely through direct communication (meuseuraya and expedition activities) and through media communication (books and social media). And there are two obstacles that MAPESA faces, namely in terms of delivering messages to the community and also technical obstacles ranging from secretariats, budgets, tools, and resources that are still minimal.
\end{abstract}

Keywords: Role, Mapesa, Introducing, History of Aceh.

\section{INTRODUCTION}

Each country has its own past history, no different from Indonesia, Indonesia's history since proclaiming its independence, Indonesia continues to go through one process to another to be a nation and a country recognized by other nations. Through the process of struggle, of course, these things will become history that can be remembered and remembered in the future.

Aceh is an area rich in cultural heritage. This statement is not merely rhetoric, but objective reality has shown that the aceh region is filled with cultural relics of the past. All the times that are divided in the history of the era of prehistoric, classical, Islamic, colonial, and independence there is evidence of its residence. Such as forts, mosques, buildings, ancient tombstones, manuscripts, currency, cemeteries, pottery and ceramics, and sites.

Aceh's current condition shows a symptom where people, especially the younger generation, are not paying attention to their past. Therefore, it is very influential in the efforts to maintain and protect historical relics that exist. In the name of development

*Address correspondence to this author at the Lecturer of Communication Sciences, Faculty of Social and Political Science, Malikussaleh University, North Aceh, Aceh, Indonesia, and Student of doctoral in Malaysia Terengganu University (UMT), Indonesia; E-mail: anismar@unimal.ac.id and progress, many historical relics are left or even destroyed. The loss of artifacts means that there are also traces of history or memory stored in them.

In addition to the many historical relics of Aceh that were destroyed due to the Aceh earthquake and tsunami in 2006, it was also destroyed by human beings who lacked historical awareness. Many of the historical relics in Aceh are lost and not clearly existed or damaged and overlooked.

Another evidence that the public's concern for historical relics is still lacking is the headstone that was used as a fence wall building in Gampong Lam Rukam, Peukan Bada, Aceh Besar, the tomb that was used as a place to lay offerings in Aceh Utara and the destruction of headstones in various areas in Aceh carried out by irresponsible people, and recently went viral on social media instagram namely the hoarding of tombs in gampong Pande, Banda Aceh, which was done deliberately by irresponsible people (https://www.instagram.com/p/Bxuj-

UWn2CB/?igshid=63soatjcs956).

The current generation not only do not care about the relics that really become history, the history also increasingly disappear from society. The advancement and development of technology today makes things happen in the world quickly in the processing of information. History is replaced by something newer. So history is sinking and completely forgotten. 
Nowadays, there are many historical communities that focus on preserving and introducing history to the community. One of them is the MAPESA community (People Care about Aceh History). MAPESA community is a community of history lovers, especially the history of Aceh, which is located in Banda Aceh. MAPESA community consisting of the younger generation (students, school students) as well as the general public who have an interest and concern for history and culture. This community was born because of concerns about the abandonment of Aceh's historical sites at that time, such as artifacts that were urgently saved, the tombs of clerics affected by abrasion, the fortresses of the Aceh kingdom that still remain neglected. There are old mosques that are not taken care of. Even the sultanate palace was lost without a trace. According to them, every part of society must take care, preserve the culture and historical evidence of Aceh.

In fact, caring for the historical site will give such many benefits. In Russia, we found that historical heritage is play a huge role in tourism development (Ismagilova,2015:157). The uniqueness of historical territories, temples, culture in certain places instead of a farm are acceptable in the market. So it increase the income of the country in the tourism sector.

This thing will get the same in Indonesia, especially Aceh, if we do care to the historical site as tombstone, and another legacy of past civilization such as Aceh Darussalam Kingdom. This is the thing the community like MAPESA try to bring the issues up, that all of the society must take care of it.

\section{LITERATURE REVIEW}

\subsection{Previous Research}

In the previous study, the author took a study conducted by Herlia Veriyanti Akbar, (2015) Faculty of Social and Political Sciences Pasundan University with her research entitled "Ethnographic Study of Communication of Aluet Community in Appreciating \& Caring about the History of Bandung City". In this research, Herlia used a qualitative research method with the ethnographic method of communion which is the method of assessment of the role of language in the communicative behavior of different cultures. In this study, Herlia wanted to know and examine the extent of appreciation and concern of the Aluet community towards the history and culture in Bandung. The focus of Herlia's research is on communication activities, communication events, and communication actions that can finally explain the appreciation and concern of the Aluet community towards the history of Bandung. In her research, Herlia used participants' observations, interviews, literature studies, and followed the activities of research objects, and documented them to add to the researchers' data. The object studied is a native community of Bandung, namely Aluet Community.

The similarity of Herlia's research with the author can be seen from the community that is examined both historical community and historical concern. Herlia researched the Bandung Silhouette Community, while researchers examined the Aceh Historical Care Community (MAPESA). But in herlia's research only examined how the communication activities of community members, while the author examined communication strategies, especially media communication used by the MAPESA community in attracting public concern for the history of Aceh. Another equation is using qualitative approach but the difference of Herlia research using cultural approach is identical with the ethnographic method of communication while the author uses the descriptive method. The location in Herlia's research took the community in Bandung, while the author took the community in Banda Aceh.

\subsection{Scope of Communication}

Etymologically (the origin of the word), communication comes from the Latin communicatius which means sharing or belonging together. The city is a communis that means common or together. Thus communication according to Lexicographer (linguist), refers to an effort aimed at sharing to achieve togetherness (Dawn, 2009:31).

Hovland, Janis, and Kelley as founded by Forsdale say that communication is the process of individuals sending stimulus which is usually in the verbal form to change the behavior of others (Muhammad, 2009:2).

Harold D Laswell (in Widya, 2017:13) also introduced 5 communication formulas for the implementation of a communication process, namely:

Who, that's acceptable to who said it.

Says what, i.e. pleased with who states what.

In which channel, i.e. pleased with what channel.

To whom, i.e. pleased with addressed to whom. 
- With what effect, i.e. pleased with what influence.

Based on the Laswell formula, there are five components of communication in order to occur the communication process, namely:

1. Communicator

Communicators are often referred to as sources, senders, encoders, talks, or originators. Sources are parties taking initiatives or have a need to communicate. The source may be an individual, a group, an organization, a company, or even a country. Sember should turn feelings or thoughts into a set of verbal and non-verbal symbols that are ideally understood by the recipient of the message.

2. Order

Message, which is what the source communicates to the recipient. Message is a verbal and non-verbal symbol that represents the feelings, values, ideas, or intentions of the source.

3. Media

Media or channels, tools or rides are used by sources to convey their message to the recipient. A channel may refer to the form of a message delivered to the recipient, whether verbal or nonverbal.

\section{Communion}

The recipient or communion, that is, the person who receives the message from the source.

\section{Effects}

The effect, that is, what happens to the recipient after he receives the message delivered by the source.

In general, we can refer to Harold Laswell's opinion that communication contains five elements of communication namely communicators, communique, messages, effects, and media. In this study, researchers referred to People Care about Aceh History (MAPESA) as communicators, communities as communique, messages, and media used as their strategy in communicating.
Communication strategies are needed so that the communication process between communicators and communique, in this case counsellors and patients, can be effective and get the desired results. To make it easier to understand the communication strategy process, there are two concepts of communication strategy, namely:

\subsection{Direct Communication (Face-to-Face)}

Indirect communication between individuals and individuals, or individuals with groups, groups with groups, groups with communities, the influence of individual relationships is included in the understanding of this communication. Direct communication is inseparable from the influence of groups, but the concept of communication is only looking at what the content of communication is built by individual communication.

This is different from the concept of group communication, where the content is influenced by the shared motivation in the group, the goals to be achieved, the shared perception, the impressions that grow in the group, the model of leadership built, and the external influences experienced by the group will affect each other members of the group, including also against the group as a whole and to some degree all individuals in that group will support each other or control each other. (Bungin in Nurcahyani, 2016:44).

Thus this communication activity, is a systematic process and forming a system consisting of components of the system, such as the context of the communicator, the context of the message and the construction of ideas, the context of interaction patterns, situational contexts, the context of individual attitudes towards the group and vice versa, and the context of tolerance. Therefore, in the direct communication activities that are contested is the understanding of the culture, values, attitudes, and beliefs of communicators.

Face-to-face communication is usually used when the communicator expects a change in the behavior change of the communique. By communicating face-toface, directly (interpersonally) we can see and use all five senses to heighten the power of persuading the message we communicate to a person.

Face-to-face communication allows a communicator to know if the communion is paying attention and understands what the communicator is saying. In other words, communicators can capture feedback directly. 
One of the descriptions of the implementation of direct communication (face-to-face) is by socialization, socialization itself is an effort to socialize something so that it becomes easily known and understood by the parties involved (Toirohmi in Nurcahyani, 2016:45).

Socialization here is more to explain the activities / communication activities to communicate a change to the target public.

The power of direct communication is to change communion behavior. While the weakness is communication that can be changed behavior only a little as far as the communicator can dialogue with communion.

\subsection{Media Communication}

Media communication is a communication process that is carried out by using the media as a channel in its delivery. According to Burhan (Nurcahyani, 2016:45) there are six important components in media communication, namely:

a. Communicators, are those who rely on modern media and technology in disseminating information, so that the information can be quickly captured by the public

b. Media, is a communication tool used in the dissemination of information, which can be accessed by the public.

c. Information (message), is a message / ideas that are intended for the mass community.

d. Gatekeeper (information selector), as it is known that the organization / institution certainly has a special division that handles information submitted through the media. It is they who select the information that will be broadcast or not broadcast.in fact they have the authority to expand, limit the information to be broadcast.

e. Public, is all human beings who receive information disseminated by the media, they consist of a public listener or a reader.

f. Feedback, in media communication, feedback is delayed (long), while in face-to-face communication is direct.

Media communication has a different process than direct communication. Because of the nature of communication that involves the media, the communication process in media communication is very complex. According to McQuail (in Nurcahyani, 2016:46) media communication activities are seen processing in several forms, namely:

a. The process of media communication is carried out in one direction, namely from communicator to communion. If there is an interactive event between them, then the communication process (back) delivered by the communion to the communicator is very limited in nature, so it is still dominated by communicators.

b. The communication process takes place in the relationships of the community needs.

Media communication is generally widely used for informative communication, because it is not so powerful to change behavior. The weakness of this communication is not persuasive, on the contrary the power of media communication can achieve great communion (Effendy, 2004:302).

\subsection{Historical Awareness}

According to Kontowijoyo (Sulistiani, 2018:18) historical awareness is an attempt to understand that a person belongs to the lamp, formed by the past and the past it touches in the present. In the life of the nation and state, more important is the awareness of collective history (together). Collective consciousness requires the public to find out, understand and act as a form of concern for history. Awareness is important for society to form identity, values of nationalism, patriotism, democratic, solidarity, honesty, justice, selfawareness, and knowledge. The act can be a desire to increase knowledge about the history and seek to preserve historical relics, be it headstones, historical sites, ancient mosques, and other objects of historical value.

The importance of human beings knowing history (historical awareness) is that history teaches about human actions in the past. From these human actions, can reflect and judge which actions are "success" and which are "failures", thus we are more able to be careful so the failure is not repeated again. By knowing history, we will always be alert to the various negative impacts of change and globalization. (Hidayati, 2012:3)

One of the attitudes towards history after people know its past is by participating in preserving historical relics and feel responsible in its maintenance because historical relics are a very meaningful historical source. 
Besides, the historical relics which have good maintenance can improve to be an object of tourism. But we need such a good strategy to reach this step (Parmawati,2020:174). Here, the responsibility for the community such as MAPESA is to communicate to the society that looking for historical heritage is important and meaningful. Then we found the strategy to increase

\section{RESEARCH RESULTS}

Banda Aceh city and Aceh Besar regency was the central kingdom of Aceh Darussalam at that time, the Kingdom of Aceh Darussalam was the second-largest work after Samudera Pasai located in North Aceh. Because of its success at that time the Kingdom of Aceh Darussalam certainly left many relics of historical sites that hid many interesting stories in it.

The historical relics of the Kingdom of Aceh Darussalam are as follows:

1. Nisan Sultan and Sultanah of the Kingdom, Religious leaders, Ministers, Darussalam Cities, and other important figures.

\section{Manuscripts.}

3. Dirham and Keuh coins became a means of exchange at that time.

4. And other relics.

In preserving cultural heritage sites, Masyarakat Peduli Sejarah Aceh (MAPESA) conducts routine activities that they refer to as Meuseuraya activities, namely gotong-royong activities in terms of laying, cleaning, and also reviewing the inscriptions of the tombstone complexes of the Kingdom of Aceh Darussalam located in Banda Aceh city and Aceh Besar regency.

\subsection{Cultural Heritage sites In Banda Aceh and Aceh Besar}

Based on MAPESA Website, here are some cultural heritage sites in Banda Aceh city and Aceh Besar regency that are late to be reviewed and traced by Masyarakat Peduli Sejarah Aceh (MAPESA), including:

\subsubsection{Banda Aceh}

The list of cultural heritage sites in Banda Aceh is divided into several sub-districts in Banda Aceh, including:
Table 1: Cultural Heritage Site In Banda Aceh City, Kuta Raja District

\begin{tabular}{|c|}
\hline Gampong Jawa \\
\hline Tombs Complex of Syahbandar Mu'tabar Khan \\
\hline Peulanggahan \\
\hline Tombs Complex of Qadhi Malikul 'Adil \\
\hline Komplek Tombs Complex of Muallim \\
\hline Gampong Pande \\
\hline Tombs Complex of Raja Ibrahim (Putroe ljo) \\
\hline Tombs Complex of Faqih Muhannad \\
\hline Tombs Complex of Sundusu Balad. \\
\hline Tombs Complex of Tun Rahmatullah Ad-Du'aliy \\
\hline Tombs Complex of Tun Kamil \\
\hline Tombs Complex of Raja-Raja Pande \\
\hline The Old Site of Kuta Meugat Building \\
\hline
\end{tabular}

Table 2: Cultural Heritage Site In Banda Aceh City,Baiturrahman District

\begin{tabular}{|c|}
\hline Kampung Baru \\
\hline Tombs Complex of Baiturrijal (Kandang XII) \\
\hline \multicolumn{1}{|c|}{ Tombs Complex of Sultan Manshur Syah } \\
\hline $\begin{array}{c}\text { Nisan 'Amidul Muluk (saved by MAPESA to Museum Aceh, at } 2 \\
\text { Marcht } 2017 \text { from Pango Raya, Ulee Kareng, Banda Aceh. Tombs } \\
\text { Complex of 'Amidul Muluk evicted by construction of Kantor Dinas } \\
\text { PU Banda Aceh City) }\end{array}$ \\
\hline Ateuk Jawo \\
\hline Tombs Complex of Asta Katib Sri Raja \\
\hline
\end{tabular}

Table 3: Cultural Heritage Site In Banda Aceh City Kec.Lueng Bata

\begin{tabular}{|c|}
\hline Sukadamai \\
\hline Blang Cut \\
\hline Tombs Complex of Tun Besar Binti Meurah Afangsali (Jeurat \\
Manyang)
\end{tabular}

Table 4: Cultural Heritage Site In Banda Aceh City Kec.Jaya Baru

\begin{tabular}{|c|}
\hline Bitai \\
\hline Tombs Complex of Tuan Maqdum \\
\hline Tombs Complex of Tengku Syiek Di Bitai \\
\hline Punge Blang Cut \\
\hline Tombs Complex of Sri Maharaja Tun Hasan \\
\hline Tombs Complex of Al Wazir Sri Tun Hasan \\
\hline
\end{tabular}


Table 5: Cultural Heritage Site In Banda Aceh City Kec.Ulee Kareng

\begin{tabular}{|c|}
\hline Ilie \\
\hline Tombs Complex of Po Teumeureuhom Ilie \\
\hline Tombs Complex of Al Wazir Sri Udahna \\
\hline Tombs Complex of Syekh Muhammad \\
\hline Tombs Complex of Adurrahim \\
\hline
\end{tabular}

Table 6: Cultural Heritage Site In Banda Aceh City Kec.Banda Raya

\begin{tabular}{|c|}
\hline Geuceu Komplek \\
\hline Tombs Complex of Raja Raden \\
\hline Geuceu Kayee Jato \\
Tombs Complex of Raja Jeumpa \\
\hline
\end{tabular}

Table 7: Cultural Heritage Site In Banda Aceh City Kec.Meuraxa

Alue Deah Teungoh

Tombs Complex of Poteumeurah

Table 8: Cultural Heritage Site In Banda Aceh City Syiah Kuala District

Tibang

Tombs Complex of Meurah Budiman

In Tables $\mathbf{1}$ to $\mathbf{8}$, explaining the information about historical sites in Banda Aceh, in the form of a complex of clerical tombs and considered as a famous hero of Aceh until now. According to Mizuar (2018), the historical sites as stated in the table above, are historical sites in the form of tombs located in the Banda Aceh area.

One of the most famous scholars is Sultan Al-Malik Ash-Shalih, on his tombstone explaining about a Muslim leader who was first held with the Sultan in Southeast Asia. He is known only by his title Al-Malik Ash-Shalih. The title that occupies the position of this name is also on some gravestones belonging to his descendants who ruled in Sumatra. From there it was known that Sultan Al-Malik Ash-Shalih was the founder of the first Islamic dynasty in Southeast Asia, both on the mainland and on the islands.

\subsubsection{Aceh Besar Regency}

The list of cultural heritage sites in Aceh Besar Regency which is divided in several districts in Aceh Besar, among them:

Table 9: Cultural Heritage Site In Aceh Besar Regency Darul Imarah District

\begin{tabular}{|c|}
\hline Gampong Lamcot \\
\hline Tombs Complex of Cot Manyang \\
\hline Tomblang Trieng Complex of Meurah Ji'ee \\
\hline Gampong Ulee Lueng \\
\hline Tombs Complex of Meurah \\
\hline Ulee Tuy \\
\hline Tombs Complex of Penghulu Fawas Maharaja Setia \\
\hline
\end{tabular}

Table 10: Cultural Heritage Site In Aceh Besar Regencylngin Jaya District

Gampong Santan

Tombs Complex of Tun Murbah Sri Rama

Table 11: Cultural Heritage Site In Aceh Besar Regency Indrapuri District

Seuramo

Tombs Complex of Sultan Alawuddin Riayat syah

Table 12: Cultural Heritage Site In Aceh Besar Regency Darul Kamal District

Turam

Tombs Complex of Sultan Muzhaffar Syah

Table 13: Cultural Heritage Site In Aceh Besar Regency Mesjid Raya District

\begin{tabular}{|c|}
\hline Lamreh \\
\hline Tombs Complex of Terpahat Indah \\
\hline Tombs Complex of Sultan Muhammad Syah \\
\hline Makam Qadhi Ismail \\
\hline
\end{tabular}

While in Tables 10 to 13 describes the historical site in the form of the tomb of the cleric in the area of Aceh Besar Regency. At the site of the tomb is a descendant of the cleric or king associated with the side of the 
descendants, for example on the tombstone of Sultan Muzhaffar Syah (d. 902 H / 1497 AD), is a figure buried and marked with a tombstone. On the tombstone, it is explained that he was a sultan.

$\mathrm{He}$ is also the grandson of a figure called Abdullah Al-Malik Al-Mubin (the servant of God the King, The Almighty). However, the tomb of the sultan's father and grandfather buried in Gampong / Biloy village, Darul Kamal District, Aceh Besar Regency, until now can not be found.

\subsection{Search for Traces of The History of The Kingdom of Aceh Darussalam}

A great kingdom must have died in a great historical footprint. This is the main reason people care about Aceh History (MAPESA) looking for traces of the history of the Kingdom of Aceh Darussalam which is the second largest Aceh kingdom after Samudera Pasai.

Traces of history that are still considered ambiguous make MAPESA seek the truth by conducting Historical Expedition activities. This activity is an activity to trace the historical traces of Aceh, especially the Kingdom of Aceh Darussalam which is based on ancient manuscripts (Manuscripts) and also inscriptions sculpted on tombstones.

From 2012 - 2020 (present). Masyarakat Peduli Sejarah or MAPESA has done several expedition activities, namely:

1. Lamreh Expedition, Aceh Besar on April 10, 2012, and May 23, 2015

2. Lhoong Expedition, Aceh Besar on 06 December 2015

3. Kuala Gigieng Expedition, Aceh Besar on October 22, 2017 and October 29, 2017

4. Indra Purwa Expedition, Aceh Besar on 07 January 2017

5. Lamno Expedition, Aceh Jaya on 04, 11, and 18 March 2018

6. Biheu Expedition, Pidie on March 30, 2019, and April 2, 2019

7. Personal expeditions by MAPESA Members are time-crossed.

\subsection{Public Awareness of Aceh's History}

In today's technological world, public awareness of history is already very lacking. For historical people, it is only the past that need not be remembered and noticed. History is just a boring discussion.

This can be proven by the loss and destruction of historical heritage sites in Aceh. For example, the destruction of historical heritage sites that are used as fences, or land complex sites that are used as residential complexes.

It is for this reason that the People Care about Aceh History (MAPESA) in various ways try to improve the knowledge, insight, and ability of the community about aceh history and awareness of aceh's historical heritage and cultural values in it.

\subsection{Integration of Marketing Concepts}

MAPESA activities in the long term need to be made breakthroughs towards more developed marketing, namely by promoting historical sites to become tourist attractions for both foreign tourists and local tourists. According to Epstein (2010) marketing is one of the functions that can bring money to every business organization, create opportunities and value, encourage competitive advantages in building the commercialization of the product development value supply chain to attract tourists to destinations in a sustainability perspective. Then, According to Ali (2016), the marketing plan is a detailed blueprint about the involvement of the role of the government, society, and tourism industry in creating value optimization and economic, social, and cultural benefits in a limited natural resources environment in a sustainable way.

\section{METHOD}

The research method is a procedure carried out by researchers to obtain data or information in obtaining answers to the problems studied. The approach that will be used in this research with a qualitative approach, where the research process and understanding is carried out by investigating a social phenomenon that is considered a problem in human life. Therefore, research can be contributed as a research strategy that can find out how the communication process in this case the communication strategy carried out by MAPESA in attracting public concern for historical relics in Aceh. 


\subsection{Data Collection Method}

According to Sugiyono (2013:224), data collection techniques are the most strategic step in research, because the main purpose of the research is to obtain data.

There are several forms of techniques that can be done in assessing the problem. In this case the data collection techniques that the author did include the following:

\section{Observation}

Sugiyono (2013:145) found that observation is a complex process, a process composed of various biological and psychological processes. And among the most important are the processes of observation and memory. The type of observation used in this study is the observation of participants. According to Riyanto (2011:98), the observation of participants is an observation where the person who observes participates in taking part in the lives of the observed person.

So in this study, researchers went directly to the field to obtain data following the objects observed, namely looking at routine activities carried out by the MAPESA Community.

\section{Interviews}

According to Sugiyono (2013:34) interview is one of the data collection techniques that can be done directly facing the interviewee. In this study, researchers used in-depth interview techniques in which the interview was very open and gave the informant the widest opportunity to explain in detail and detail about the problems studied.

\section{Documentation}

Documentation according to Sugiyono (2009:240), is a record of events that have passed. The documentation used by researchers here is in the form of photos, pictures, and recordings of interviews in the form of video or voice recordings.

\section{Literature Studies}

This aims to find additional references to the problems to be examined. In this case, researchers need books, journals, and other literature related to research.

\subsection{Research Paradigm}

The Research paradigm in this research is qualitative data analysis as stated by Miles and Hebermen in Basrowi (2008:209) in his book entitled Understanding Qualitative Research mentions that the data analysis includes three concurrent activities, namely reduction, presentation of data and concluding.

1. Data reduction, i.e. selection, centering, attention, simplification, abstraction, and transformation of abusive data emerging from written records from the field. This process takes place during the research conducted from the beginning to the end of the research. Data obtained from research locations or field data is outlined in a complete and detailed description or report. Researchers reduce data because there is data that is not by the focus of the research, then the data is the author discards and looks for accurate and accountable data.

2. Data presentation is a set of composed information that provides the possibility to be used in drawing conclusions and taking action by looking at the presentation of data, then researchers can understand what is going on and what to do to make it easier for researchers to see the overall picture or certain parts of the researcher, in other words is organizing the data in a certain form so that it is more clearly visible the results of the study. Forms of presentation include narrative text, matrices, graphs, networks, and sections.

3. Withdrawal of conclusions and verification is an activity to deduce the meanings that arise from the data tested its correctness, robustness, and suitability. Conclusions are also verified during the study, the meanings that arise from the data must always be tested for truth and conformity so that its validity is guaranteed.

\section{RESULT \& DISCUSSION}

Mapesa (Masyarakat Peduli Sejarah Aceh) strategy is formulated in the vision, mission, objectives, and evaluation of previously planned achievements. The strategy was prepared to provide direction and guidelines for MAPESA (Masyarakat Peduli Sejarah Aceh) about the ways necessary to achieve the strategic objectives. 
Based on observation data that has been done by researchers in the field, it appears that the presence of MAPESA Community (Masyarakat Peduli Sejarah Aceh) has a very important role in terms of Aceh History, especially the preservation of Aceh historical sites and facts about the story of the ancient Aceh Kingdom. The MAPESA Community (Masyarakat Peduli Sejarah Aceh) should have maximum strength in trying to increase knowledge about Aceh's history that is still unknown to most people. So by the desired objectives, the MAPESA Community (Masyarakat Peduli Sejarah Aceh) has carried out a form of communication strategy, both in-person (face-to-face) and media to members and the wider community.

Direct communication (face-to-face) conducted by the MAPESA Community (Masyarakat Peduli Sejarah Aceh) is by socializing the historical heritage of Aceh spread in banda Aceh and Aceh besar through their routine activities, namely Meuseuraya.

The implementation of direct communication strategy through meuseuraya (gotong royong) routine activities carried out by the Aceh Historical Care Community (MAPESA) in introducing Aceh's history to the community, apparently brings a positive direction in the community's concern for the relics of Aceh's current history. The community welcomes the Meuseuraya activities carried out by the Aceh Historical Care Community (MAPESA), in other words, the activities that the Community Cares for Aceh History (MAPESA) are not in vain. Also, the community participates in participating in carrying out these activities.

In addition to direct communication, MAPESA also uses the strategy of using media as their intermediary in disseminating Aceh's history to the public, namely by using mass media such as print media (books, information boards) and also social media (websites, Facebook, Instagram, and Youtube).

These strategies are a way that the MAPESA Community (Masyarakat Peduli Sejarah Aceh) does in introducing Aceh's history to the wider community, because to get a wider mass (community) they can not only use direct communication because not all people want to participate in their activities.

From the observation of researchers, the cooperation that often Community Cares for Aceh History (MAPESA) is done is with various elements of society such as historians, communities, and historical activists who care about history is not just to do the name and financial just like the government.
Based on research and observations that have been done by researchers, the strategy of Komunitas Masyarakat Peduli Sejarah Aceh in fulfilling history to the community, researchers see in terms of strategies used have been very effective and have been very following technology. This can be proven by communication through the media they use.

But public awareness of history is still very lacking. This is because both in direct communication and media communication. Because not all people follow the activities or see the posts that the Community Cares about Aceh History (MAPESA) share

Since the strategies are underway, the impact of the Aceh Historical Care Community (MAPESA) on public awareness of Aceh's history has a positive point, people today play an active role in informing the history around it.

\section{CONCLUSION}

In this research, the message that the Community cares about Aceh History (MAPESA) wants to convey is the introduction of history and awareness of the importance of historical relics for a better future.

In delivering a message, a medium is required. Media is an intermediary in the delivery of information from communicators to communiques aimed at the efficiency of the dissemination of such information or messages.

The way to communicate in this research is directly or face-to-face and media. Direct communication referred to in the Aceh Historical Care Community (MAPESA) community is through their field activities in saving historical sites, while media communication in the MAPESA Community is to publish books about history, then share them with the public, and use social media such as facebook, instagram, youtube, and also websites to get a wider audience.

1. Communication strategy conducted by Komunitas Masyarakat Peduli Sejarah Aceh (MAPESA) in introducing Aceh history to the community by using the strategy directly, namely meuseuraya and expedition activities. And the strategy of media through print media (books), and online media (Facebook, Instagram, youtube, and website), where the strategy carried out by the Community Cares for The History of Aceh (MAPESA) has been carried out well following their vision and mission. 
2. There are obstacles faced by the Community Care for Aceh History (MAPESA) in preserving Aceh's historical heritage, namely obstacles in the delivery of messages and also technically starting from the budget, supporting tools, and also human resources.

There are four social media accounts managed by the MAPESA (Masyarakat Peduli Sejarah Aceh) community, namely:

1. Facebook Group account named MAPESA "Masyarakat Peduli Sejarah Aceh". This account was created in 2009 but was originally named GPPSA (Next Generation and Care for Aceh History). And in 2012 it changed its name to MAPESA "Masyarakat Peduli Sejarah Aceh" after the change of community name. The account currently has 45,898 followers.

2. Instagram account @mapesa_aceh, this account was formed on November 11, 2016. This account has been followed by 3,232 people to date. With 619 posts.

3. Website Account Mapesaaceh.com, this account was formed in July 2015. In this account, many aspects ranging from the cultural heritage site map, Bandar-Bandar (city center of civilization) history of Aceh in an ancient kingdom, and headlines such as archaeology, architecture, news, a history gallery, inscriptions of tombstones, activity reports, manuscripts (ancient manuscripts), MAPESA activities, numanistics, opinions and historical posters, and poetry.

4. Mapesa Aceh Youtube account, a post entitled "Diwai Makam historical site, Lambaro Skep
Kota Banda Aceh", was the beginning of the establishment of mapesa community youtube account on August 21, 2015.

\section{REFERENCES}

Hasan, Ali (2016), Tourism Marketing. CAPS (Center for Academic Publishing Service), Jakarta

Baswori, Sumandi. 2008. Understanding Qualitatif Research. Jakarta: Rineka Cipta.

Effendy, Onong Uchjana. 2004. Communication Dynamics. Bandung: PT Remaja Rosdakarya.

Epstein, M., Buhovac. A. And Yuthas, K. 2010. Implementing Sustainability: the role of leadership and organizational culture. Stategic Finance, 91(10). 41-47.

Fajar, Marhaeni. 2009.Communication science practice \& theory. Yogyakarta: Graha IImu.

Hidayati, Nur \& Abraham Nurcahyo. 2012. Historical Awareness and Community Participation in The Preservation of General Soedirman Monument (Case in Pakis Baru Village, Nawangan District, Pacitan Regency) Vol 02 No. 01

Ismagilova, Gulnara,. Lenar Safiullin, and Ilshat Gavurov. Using Historical Heritage As A Factor in Tourism Development. Procedia, Social and Behavioral Sciences.2015. Vol. 188, page 157-162. https://doi.org/10.1016/j.sbspro.2015.03.355

Mahdi, Mizuar 2018. Traversing the Historical Trail of Aceh, MAPESA, Banda Aceh

Maruapey, Widya Aztriny. 2017. Communication Strategy of Local Government Institutions in Handling The Problem of Teacher Professional Allowance in 2015 (Case Study in The Planning and Finance Section of the Education and Culture Office of Central Maluku Regency.FISIP University of Muhammadiyah Malang.

Parmawati, Rita., Edriana Pangestuti, Wike, Rizha Hardyansah. Development and Sustainable Tourism Strategies in Red Islands Beach, Banyuwangi Regency. Journal of Indonesian Tourism and Development Studies. 2020. Vol.8 No.3 Page: 174-180

Sugiyono. 2009. Quantitative, Qualitative and R\&D Research Methods. Bandung: Alfabeta.

2013. Quantitative, Qualitative, and R\&amp;D Research Method of Cet XIV. Bandung: Alfabeta.

Sulistiani, Eka. 2018. Efforts to Establish Awareness and Awareness of Community History: Cultural Exploration Community (2003-2013). Faculty of Social Sciences, State University of Jakarta.

\begin{tabular}{llc}
\hline Received on 11-01-2021 & Accepted on 16-03-2021 & Published on 11-05-2021
\end{tabular}

https://doi.org/10.6000/1929-4409.2021.10.115

(C) 2021 Anismar et al.; Licensee Lifescience Global.

This is an open access article licensed under the terms of the Creative Commons Attribution Non-Commercial License (http://creativecommons.org/licenses/by-nc/3.0/) which permits unrestricted, non-commercial use, distribution and reproduction in any medium, provided the work is properly cited. 